\title{
Review
}

\section{Biological Control in Brazil: An overview}

\author{
José Roberto Postali Parra*
}

University of São Paulo/ESALQ - Dept. of Entomology and Acarology, C.P. 09 - 13418-900 - Piracicaba, SP - Brazil.

*Corresponding author <jrpparra@usp.br>

Edited by: Paulo Cesar Sentelhas
ABSTRACT: The use of Biological Control methods is on the increase, mainly as a result of the mobilization of human resources in entomology studies since the establishment of graduate programs in this country in the 1960s. This review approaches the retrospective of Biological Control in Brazil in recent decades, with an emphasis on the "culture of applying agrochemicals" adopted by Brazilian growers, which constrains progress in this area. Successful cases of Biological Control have been reported on in Brazil and there are, in fact, excellent programs in place that use insects or entomopathogenic microrganisms for insect pest control. Most of the studies in this area have been published in Portuguese and are, therefore, not readily available internationally. Importantly, half of the planted sugarcane (Saccharum officinarum), around four million hectares, is treated with natural enemies (insects) and/or pathogens. In contrast to other countries that employ Biological Control in small areas, the challenge in Brazil is to implement programs in large farms. Many obstacles must be overcome and discussed in working groups so that we can assume a world leadership position in the use of Biological Control in tropical regions as Brazil is already considered the leader in tropical agriculture. In this review, use of Biological Control is discussed within the Integrated Pest Management philosophy, as a path toward sustainable agriculture that is in harmony with other pest control methods. We must develop a technology of Biological Control adapted to tropical regions, rather than copying models developed for temperate regions, which are usually inappropriate for Brazilian conditions.

Keywords: tropical agriculture, entomology, integrated pest management, sustainable agriculture
Aphelinidae, previously called Prospaltella berlesei) to control white peach scale, Pseudaulacaspis pentagona (Targioni) (Hemiptera: Diaspididae), was, unfortunately, not completely successful. Other cases using imported natural enemies are mentioned in the section "History of Biological Control in Brazil." Despite the progress made in the use of BC, the "Culture of Chemical Control" prevailed and reached a peak with the synthesis of DDT (Dichlorodiphenyltrichloroethane) in 1939, which won Paul Müller the Nobel Prize and prompted the massive use of chemicals until the early 1960s. In 1962, Rachel Carson published "Silent Spring," alerting the general public to problems associated with the abusive use of pesticides. As a result, people became more aware of problems related to the indiscriminate use of chemicals, including ecological imbalances; the development of insect and mite resistance to agrochemicals (to date, more than 500 resistant pests have been identified); outbreak of secondary pests; resurgence of pests; harmful effects on human beings, natural enemies of pests, fish and other non-target animals, in addition to persistent chemical residues in food, water and soil (Carson, 1962).

The so-called "dark age of pest control" from 1940 to 1960 (Kogan, 1998) motivated the scientific community to propose a novel philosophy of Pest Control based on not only economic, but also ecological and social considerations. IPM (Integrated Pest Management) has arisen as a response of the scientific community to solve problems originating from the abusive use of chemicals. 
The IPM approach is defined as a combination of control tactics with the aim of keeping pest population densities below the economic threshold, taking into account economic, ecological and social criteria.

These tactics include pest control methods (Figure 1) (Leppla and Williams, 1992): (i) cultural, (ii) behavioral (pheromones), (iii) plants resistant against insects, (iv) chemical and, more recently, (v) transgenic varieties. Also included is Biological Control, which occupies an important position since natural enemies are responsible for balance in the agroecosystem and therefore. Their populations should be maintained or increased in nature by means of inoculative or inundative releases. However, for the implementation of a successful IPM program, pesticides can also be employed if they are selective and do not eliminate natural enemies, and kill only the pests. Systematic use of the same active ingredient, e.g., the same Insecticide Resistance Action Committee (IRAC) group of chemical insecticides, must be avoided in order to prevent the development of resistant pests.

In this context, the general public began to demonstrate its awareness and to organize itself in opposition to the irrational use of chemicals in agriculture. This movement developed between 1960 and 1970, and became radicalized in several countries. In Spain, for instance, considerably fewer and smaller amounts of pesticides are currently in use, and some of them have been banned from use on some crops such as peppers. To implement $\mathrm{BC}$, it is necessary to "master techniques of rearing insects in the laboratory" so that natural enemies can be released in nature in an attempt to reestablish balance in the agroecosystem.

In Brazil, several problems limit the crop area where BC is employed. However, the cultural aspect is the most important element that limits the use of $\mathrm{BC}$, since the average Brazilian grower is used to killing insects (they ensure that dead insects fall on the ground after spraying chemicals), but not used to rearing them in the laboratory (in 2013, US $\$ 11$ billion was spent on

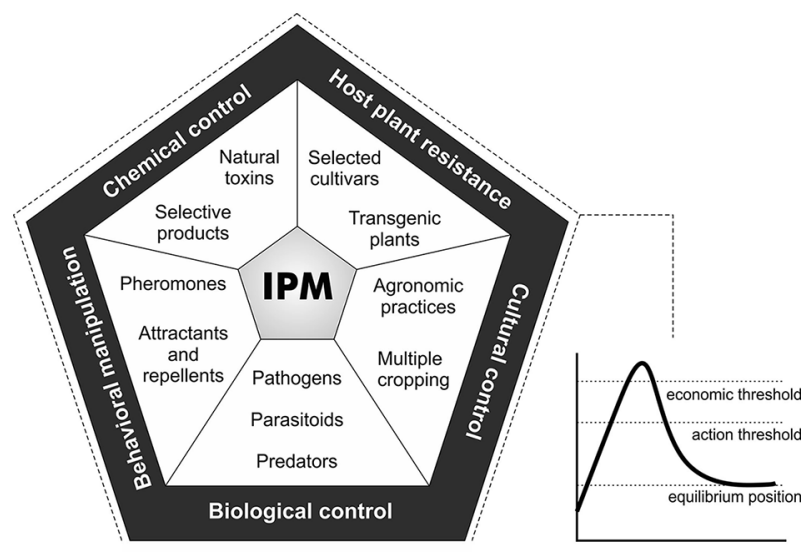

Figure 1 - Control tactics used in IPM (Integrated Pest Management), modified from Leppla and Williams (1992). chemical pesticides in Brazil). Furthermore, because Brazil is a leader in tropical agriculture, which has undergone extensive technological development in recent years, areas supporting only one crop (for example, soybeans - Glycine max, cotton - Gossypium hirsutum, or corn - Zea mays etc.) can reach 20,000 - 30,000 and sometimes 100,000 ha, for a single grower. Thus, there is a need to develop monitoring techniques in these vast areas in order to release natural enemies at the right time. It is not possible to fully adopt methods from European agriculture, where BC is often used in greenhouses, such as in the Netherlands. There are clearly obstacles to be overcome to effect an increase in the use of BC in our country, where the biodiversity is unequaled and many $\mathrm{BC}$ agents are now available for use in Brazilian agriculture.

This review aimed to show that areas treated with Biological Control have tended to increase in Brazil, and, in some cases, the BC treated crop is among the world's largest farmlands. Once obstacles such as those that have already occurred in agricultural practices in general are overcome with the development of this particular technology, we will be leaders in the use of BC in tropical agriculture. The number of specialists in BC who have been educated in Brazilian universities over the last 50 years will contribute substantially to the successful development of BC methods. Over this period, $25 \%$ of the Master and Doctoral students in entomology have presented dissertations or theses on BC.

Multinational companies that produce pesticides have begun to sense that $\mathrm{BC}$ will continue to grow, and as a result, have been acquiring $\mathrm{BC}$ companies, particularly those related to entomopathogenic microrganisms. There are several reasons for this change in mindset, including the time-consuming work on the synthesis of novel molecules and the consequent high costs of synthesizing them, which can reach more than US $\$ 250$ million per new product. Moreover, transgenic plants have not fulfilled the promise to be a solution for all problems. Nowadays, the total area occupied by transgenic varieties is about 40 million ha in Brazil.

Crop production in Brazil has progressively grown in response to the demands of the international market, which are very restrictive as regards chemical residues. To reduce pesticides in crops, the use of BC serves as a solution to export requirements and, also obviously serves the national demand for IPM programs. Reviews of BC in Latin America have been written by Bennet (1992) and van Lenteren and Bueno (2003).

\section{History of biological control in Brazil, and certain successful cases}

Before DDT was synthesized, natural enemies introduced were already in use, the first being the aphelinid $E$. berlesei from the USA. Importation of natural enemies into Brazil continued until 1944 (Table 1) (Parra, 2011), but introductions did not result in successful BC because, at that time, no systematic studies of insect rearing or inter- and multi-disciplinary programs exist- 
Table 1 - Introductions of natural enemies used for biological control in Brazil.

\begin{tabular}{|c|c|c|c|}
\hline Target Pest & Year of introduction & Origin & Natural Enemy \\
\hline $\begin{array}{l}\text { Pseudaulacaspis pentagona } \\
\text { (Hemiptera: Diaspididae) }\end{array}$ & 1921 & USA & $\begin{array}{l}\text { Encarsia berlesei } \\
\text { (Hymenoptera: Aphelinidae) }\end{array}$ \\
\hline $\begin{array}{l}\text { Hypothenemus hampei } \\
\text { (Coleoptera: Curculionidae) }\end{array}$ & 1923 & Africa & $\begin{array}{l}\text { Prorops nasuta } \\
\text { (Hymenoptera: Bethylidae) }\end{array}$ \\
\hline $\begin{array}{l}\text { Eriosoma lanigerum } \\
\text { (Hemiptera: Aphididae) }\end{array}$ & 1928 & Uruguay & $\begin{array}{l}\text { Aphelinus mali } \\
\text { (Hymenoptera: Encyrtidae) }\end{array}$ \\
\hline $\begin{array}{l}\text { Ceratitis capitata } \\
\text { (Diptera: Tephritidae) }\end{array}$ & 1937 & $\begin{array}{l}\text { USA } \\
\text { (Hawaii) }\end{array}$ & $\begin{array}{l}\text { Tetrastichus giffardianus } \\
\text { (Hymenoptera: Eulophidae) }\end{array}$ \\
\hline Grapholita molesta (Lepidoptera: Tortricidae) & 1944 & USA & $\begin{array}{l}\text { Macrocentrus ancylivorus } \\
\text { (Hymenoptera: Braconidae) }\end{array}$ \\
\hline $\begin{array}{l}\text { Antonina graminis } \\
\text { (Hemiptera: Pseudococcidae) }\end{array}$ & 1967 & $\begin{array}{l}\text { USA } \\
\text { (Texas) }\end{array}$ & $\begin{array}{l}\text { Neodusmetia sangwani } \\
\text { (Hymenoptera: Encyrtidae) }\end{array}$ \\
\hline $\begin{array}{l}\text { Diatraea saccharalis } \\
\text { (Lepidoptera: Crambidae) }\end{array}$ & 1970s & Trinidad and Tobago, Pakistan & $\begin{array}{l}\text { Cotesia flavipes } \\
\text { (Hymenoptera: Braconidae) }\end{array}$ \\
\hline Wheat aphids & 1970s & Many countries & Parasitoids and predadors \\
\hline $\begin{array}{l}\text { Tuta absoluta } \\
\text { (Lepidoptera: Gelechiidae) }\end{array}$ & $1990 \mathrm{~s}$ & Colombia & $\begin{array}{l}\text { Trichogramma pretiosum } \\
\text { (Hymenoptera: Trichogrammatidae) }\end{array}$ \\
\hline $\begin{array}{l}\text { Phyllocnistis citrella } \\
\text { (Lepidoptera: Gracillariidae) }\end{array}$ & 1998 & USA (Florida) & $\begin{array}{l}\text { Ageniaspis citricola } \\
\text { (Hymenoptera: Encyrtidae) }\end{array}$ \\
\hline
\end{tabular}

ed. The few isolated BC programs were conducted by individual researchers.

Following the last introduction in 1944, Brazilian $\mathrm{BC}$ passed through a depressed period when large amounts of organic synthetic pesticides were used against pests, a period that includes the "dark ages" of pest control, as mentioned above (Kogan, 1998). In 1967, introductions of natural enemies resumed (Table 1) (Parra, 2011). The table provides a limited number of examples, because importation of natural enemies accelerated only after the "Costa Lima" quarantine system was established by Embrapa (Brazilian Agricultural Research Corporation) in Jaguariúna, in the state of São Paulo. Since the establishment of the quarantine system in 1991, around 772 species of natural enemies, such as parasitoids, predators (including mites), and pathogens have been imported. Recently, a number of natural enemies have been imported to control certain recentlyappearing forest pests in Brazil, e.g., Psyllaephagus bliteus Riek (Hymenoptera: Encyrtidae) to control the red gum lerp psyllid and Cleruchoides noackae Lin and Huber (Hymenoptera: Mymaridae) to control the bronze bug Thaumastocoris peregrinus Carpintero and Dellapé (Hemiptera: Thaumastocoridae).

At the beginning of the $\mathrm{BC}$ efforts, insects (parasitoids and predators) were imported and colonized with the aim of controlling exotic pests and, eventually, native ones. Although exotic species were originally used, from 2000 through 2009, the use of native natural enemies predominated, representing $76 \%$ of biological control species compared with $42 \%$ during the $1960-1985$ period (Cock et al., 2010). This is termed "Classical Biological Control", which can be implemented by means of in- oculative releases using a small number of insects. This is a long-term method, since a natural-enemy population tends to increase over time, so it works well for pests of perennial or semi-perennial crops. Initially, knowledge of insect rearing methods was limited, so inundative releases, which are used in applied or augmentative BC, were not feasible. As this method can control a pest population faster than classical BC (similarly to pesticides), it is more widely accepted by growers (especially in Brazil), but it requires mass rearing of insects.

Real progress in Biological Control in Brazil began in the 1970s, aided by several important factors (Parra, 2011):

1 - The founding of graduate schools in Brazil in the 1960s: Since 1969, around $25 \%$ of recipients of master and doctoral degrees in Brazil have acquired expertise in BC. During this period, Embrapa was founded, and the number of Brazilian entomologists trained abroad increased substantially. Graduate schools were established across the country, and some $\mathrm{BC}$ research groups were created, using inter- and multidisciplinary approaches;

2 - Changes in entomologists' mindset: As researchers began to specialize in entomology, a change in mindset occurred, so that the general idea was no longer simply "to kill" insects, but to rear them. This new attitude led to the development of mass-rearing methods to produce insects for inundative releases ("Augmentative or Applied Biological Control"). The 1960-1970 period coincided with the implementation of IPM, which required the development of host rearing techniques (natural or alternative) for use in $\mathrm{BC}$ programs. 
As a result, the literature on $\mathrm{BC}$ has expanded enormously in both national and international research with the number of publications on insect rearing techniques following the same trend. Some examples include the reports by Smith (1966), Singh (1977), Singh and Moore (1985), Cohen (2004) and Schneider (2009), and Brazilian publications, such as those of Parra and Zucchi (1997), Parra (2001), Parra et al. (2002), Parra (2008), Bueno (2000; 2009), Pinto et al. (2006) and Cônsoli et al. (2010), among others, about insect rearing and Biological Control. This was the starting point for the creation of insect mass-rearing facilities (Parra, 2008; 2010). These facilities were initially financed by the federal government and national programs, but, currently, they are being developed by private companies to supply the expanding market for BC agents. In 1969, Professor Domingos Gallo, Head of the Department of Entomology of the College of Agriculture Luiz de Queiroz (Escola Superior de Agricultura Luiz de Queiroz - ESALQ) of the University of Sao Paulo (Universidade de São Paulo - USP) at the time, and responsible for the initiative of developing a $\mathrm{BC}$ program for sugarcane pest control in Brazil, began in 1969 to use artificial diets for Diatraea saccharalis (F.) (Lepidoptera: Crambidae) with the objective of producing the native Tachinidae Lydella minense (Towns.) and Billaea claripalpis Wulp (Diptera: Tachnidae). This started one year after the publication of the artificial diet for D. saccharalis by Hensley and Hammond (1968).

Before Cotesia flavipes Cameron (Hymenoptera: Braconidae) was introduced to control $D$. saccharalis by Planalsucar (at the time associated with the Institute of Sugar and Alcohol, no longer in existence), Prof. Gallo had already attempted to introduce the Cuban-fly, Lixophaga diatraeae (Towns.) (Diptera: Tachnidae). Unfortunately, this fly did not adapt to conditions in most Brazilian states.

3 - Foundation of the Entomological Society of Brazil (SEB) in 1972: The SEB has organized its conferences and Siconbiol (Symposium of Biological Control) in alternate years. Each event promotes communication among experts in the field.

The first graduate course on BC in Brazil, offered at ESALQ/USP, began in 1975 under the supervision of Prof. Domingos Gallo, and later by Prof. Evôneo Berti Filho. In 1974, a course on Insect Pathology was implemented at the same institution, initially supervised by Prof. Nelson Suplicy Filho of the Biological Institute of São Paulo, and then by Prof. Sérgio Batista Alves of the Department of Entomology of ESALQ/USP, who passed away in 2009. An additional factor that contributed to the expansion of $\mathrm{BC}$ in Brazil was the release of the "Fourth Catalogue of Insects that Live on Plants from Brazil: Their Parasites and Predators" by Silva et al. (1968). This catalogue was a milestone in the history of BC in Brazil, and coincided with the $1^{\text {st }}$ Symposium on Biological Control held in the Institute of Ecology and Agricultural Experimentation, in Rio de Janeiro.
Other courses have also contributed to the progress of BC: in 1990, a course conducted at ESALQ/USP by professors from the University of California, Berkeley, was attended by Brazilian and Latin American researchers and included founders of modern BC such as Dr. Kenneth S. Hagen. Beginning in the 1950s, extension courses including "Rearing Techniques and Insect Nutrition for Biological Control Programs" were given across Brazil under the coordination of Prof. José R. P. Parra, contributing to the propagation and updating of $\mathrm{BC}$.

All these factors, combined with the training of people in insect rearing, a basic element for the production of natural enemies, have hastened advances in the management of several crops in Brazil. In particular, sugarcane, which currently covers half of the cultivated land (more than 8 million ha) in the country, is treated by $\mathrm{BC}$ to control the sugarcane borer $D$. saccharalis (with C. flavipes and Trichogramma galloi Zucchi) and the spittlebug Mahanarva fimbriolata Stål (Hemiptera: Cercopidae) (with Metarhizium anisopliae).

Based on current knowledge, it is necessary to rear two insect species, the pest (or an alternative host) and the natural enemy, in order to develop BC programs that use parasitoids and/or predators. The introduction of methods for in vitro insect rearing using artificial diets created high expectations during the 1980s, particularly after the successful in vitro production of Trichogramma dendrolimi Matsumura (Hymenoptera: Trichogrammatidae) (Li-Ying et al., 1988) by Chinese researchers. Although no significant advances were made in world technology for in vitro insect rearing, some promising results were obtained in Brazil for Trichogramma pretiosum Riley, T. galloi (Cônsoli and Parra, 1999) and Trichogramma atopovirilia Oatman and Platner (Dias et al., 2010) as well as for the ectoparasitoid Bracon hebetor Say (Hymenoptera: Braconidae) (Magro and Parra, 2004).

\section{Successful cases in Brazil}

Beginning in the 1960-1970 decade, the use of BC in Brazil has continued to expand. The evolution of $\mathrm{BC}$ in the country is a result of programs that followed sequential steps involving researchers from different areas. One example was a program using Trichogramma, which had a French influence, especially in the person of Dr. Jean Voegelé of INRA (Institut National de la Recherche Agronomique) in Antibes, and was initiated in Brazil to control forest (Moraes et al., 1983) and agricultural pests in Piracicaba in 1984 (Parra and Zucchi, 2004).

Such programs, especially those dealing with agricultural pests, led to important advances, from the initial steps of collection, identification and maintenance of Trichogramma strains to cost/benefit assessment evaluations. As a result, research groups were formed in different areas of the country, and a large amount of basic information about the topic was published. Currently, this egg parasitoid is widely used in several crops including vegetables, sugarcane, corn, soybeans and cotton, among others (Parra and Zucchi, 2004). 
The most efficient BC program in Brazil, which is among the best in the world, is conducted to control the main pests that target sugarcane, D. saccharalis and $M$. fimbriolata. To control $D$. saccharalis, 3.3 million ha are currently being treated with C. flavipes. In 2010, T. galloi was also used on 500,000 ha of sugarcane to control the eggs of the sugarcane borer (Parra et al., 2010a) (Figure 2). Mahanarva fimbriolata is controlled with the fungus M. anisopliae, covering an area of 2 million ha.

The main insect species used to control insects in Brazil are listed in Table 2 (Parra et al., 2011) and some of them are shown in Figure 3. Other, less extensive programs are also important, such as that used to control forest pests initiated in the 1960s by Prof. Evôneo Berti Filho, of ESALQ/USP, currently coordinated by

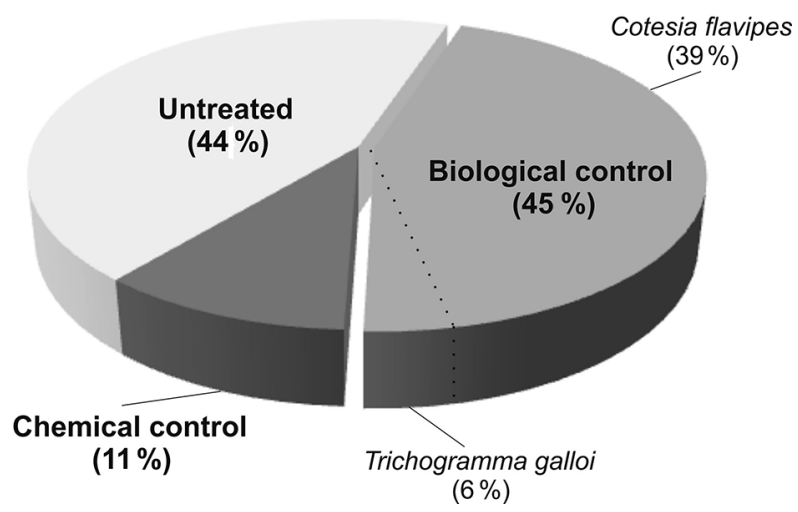

Figure 2 - Percentage of the sugarcane area in Brazil, treated with releases of natural enemies.
Prof. José Cola Zanuncio, of Federal University of Viçosa (Universidade Federal de Viçosa - UFV), and Prof. Carlos Frederico Wilcken, of the São Paulo State University (Universidade Estadual Paulista - UNESP), Botucatu. Another research program on phytoseiid mites is conducted by Prof. Gilberto José de Moraes, of ESALQ/USP.

Although it is not the central topic of this review, it is worth mentioning that microbial pest control is progressing well in Brazil. There are examples of BC programs conducted on several crops and commercially available products with formulations of Bacillus thuringiensis for controlling caterpillars and Beauveria bassiana, Metarhizium anisopliae, Baculovirus anticarsia; Trichoderma harzianum for controlling several agricultural pests, diseases and even nematodes, such as Deladenus siricidicola, for controlling Sirex in Pinus (Alves, 1986; 1998; Alves and Lopes, 2008). Approximately 20 companies are presently marketing BC agents (insects and mites) in Brazil to control pests in sugarcane, soybeans, tomato - Lycopersicon esculentum, cotton etc., and another 30 companies are producing pathogens. Approximately 20 laboratories at sugarcane mills are producing $C$. flavipes to control $D$. saccharalis, and $M$. anisopliae to control $M$. fimbriolata. These are either national or international companies, including multinational pesticide companies that grow pathogens or insects for applications in the biological control of pests.

The biocontrol species presently being marketed in Brail include two in the genus Trichogramma, T. pretiosum and T. galloi, and the braconid C. flavipes. Predatory mites (Neoseiulus californicus, Phytoseiulus macropilis, $P$. longipes, Stratiolaelaps scimitus) are sold for controlling tetranychids, tarsonemids, Bradysia, Collembola, soil mites and thrips (Parra et al., 2011). Bracon hebetor is produced

Table 2 - Successful cases of Classical and Applied Biological Control in Brazil (Parra et al., 2011).

\begin{tabular}{|c|c|c|c|c|}
\hline Crop & Period & Target Pest & Natural Enemy & References \\
\hline \multicolumn{5}{|c|}{ Classic Biological Control } \\
\hline Pasture grasses & $\begin{array}{l}\text { 1960s } \\
\text { until the present }\end{array}$ & $\begin{array}{l}\text { Rhodes grass scale Antonina graminis } \\
\text { (Hemiptera: Pseudococcidae) }\end{array}$ & $\begin{array}{l}\text { Neodusmetia sangwani } \\
\text { (Hymenoptera: Encyrtidae) }\end{array}$ & Gallo et al. (2002) \\
\hline Wheat & $1970 s$ & $\begin{array}{l}\text { Wheat aphids } \\
\text { (Hemiptera: Aphididae) }\end{array}$ & $\begin{array}{l}\text { Praon, Ephedrus and Aphidius } \\
\text { (Hymenoptera: Braconidae) }\end{array}$ & Salvadori and Salles (2002) \\
\hline Cassava & $1990 s$ & $\begin{array}{l}\text { Cassava mealybug Phenacoccus herreni } \\
\text { (Hemiptera: Pseudococcidae) }\end{array}$ & $\begin{array}{l}\text { Acerophagus coccois, Anagyrus } \\
\text { diversicornis and Aenasius vexans } \\
\text { (Hymenoptera: Encyrtidae) }\end{array}$ & Bento et al. (2002) \\
\hline Citrus & 1990 s and 2000 s & $\begin{array}{l}\text { Citrus leaf miner, Phyllocnistis citrella } \\
\text { (Gracillariidae) }\end{array}$ & $\begin{array}{l}\text { Ageniaspis citricola (Hymenoptera: } \\
\text { Encyrtidae) }\end{array}$ & Parra et al. (2004) \\
\hline \multicolumn{5}{|c|}{ Applied Biological Control } \\
\hline Industrial tomatoes & $1990 s$ & Tuta absoluta (Lepidoptera: Gelechiidae) & $\begin{array}{l}\text { Trichogramma pretiosum (Hymenop- } \\
\text { tera: Trichogrammatidae) }\end{array}$ & Haji et al. (2002) \\
\hline Soybeans & 1980 s and 1990 s & $\begin{array}{l}\text { Soybean stink bugs (Hemiptera: } \\
\text { Pentatomidae) }\end{array}$ & $\begin{array}{l}\text { Trissolcus basalis (Hymenoptera: } \\
\text { Platygastridae) }\end{array}$ & Corrêa-Ferreira (2002) \\
\hline Sugarcane & 1970s until the present & $\begin{array}{l}\text { Sugarcane borer, Diatraea saccharalis } \\
\text { (Lepidoptera: Crambidae) }\end{array}$ & $\begin{array}{l}\text { Cotesia flavipes (Hymenoptera: } \\
\text { Braconidae) }\end{array}$ & $\begin{array}{l}\text { Botelho and Macedo } \\
\text { (2002) }\end{array}$ \\
\hline Sugarcane & $\begin{array}{l}\text { 1980s (beginning of } \\
\text { studies) } \\
\text { until the present }\end{array}$ & $\begin{array}{l}\text { Sugarcane borer, Diatraea saccharalis } \\
\text { (Lepidoptera: Crambidae) }\end{array}$ & $\begin{array}{l}\text { Trichogramma galloi (Hymenoptera: } \\
\text { Trichogrammatidae) }\end{array}$ & $\begin{array}{l}\text { Parra, Botelho and Pinto } \\
\text { (2010) }\end{array}$ \\
\hline
\end{tabular}




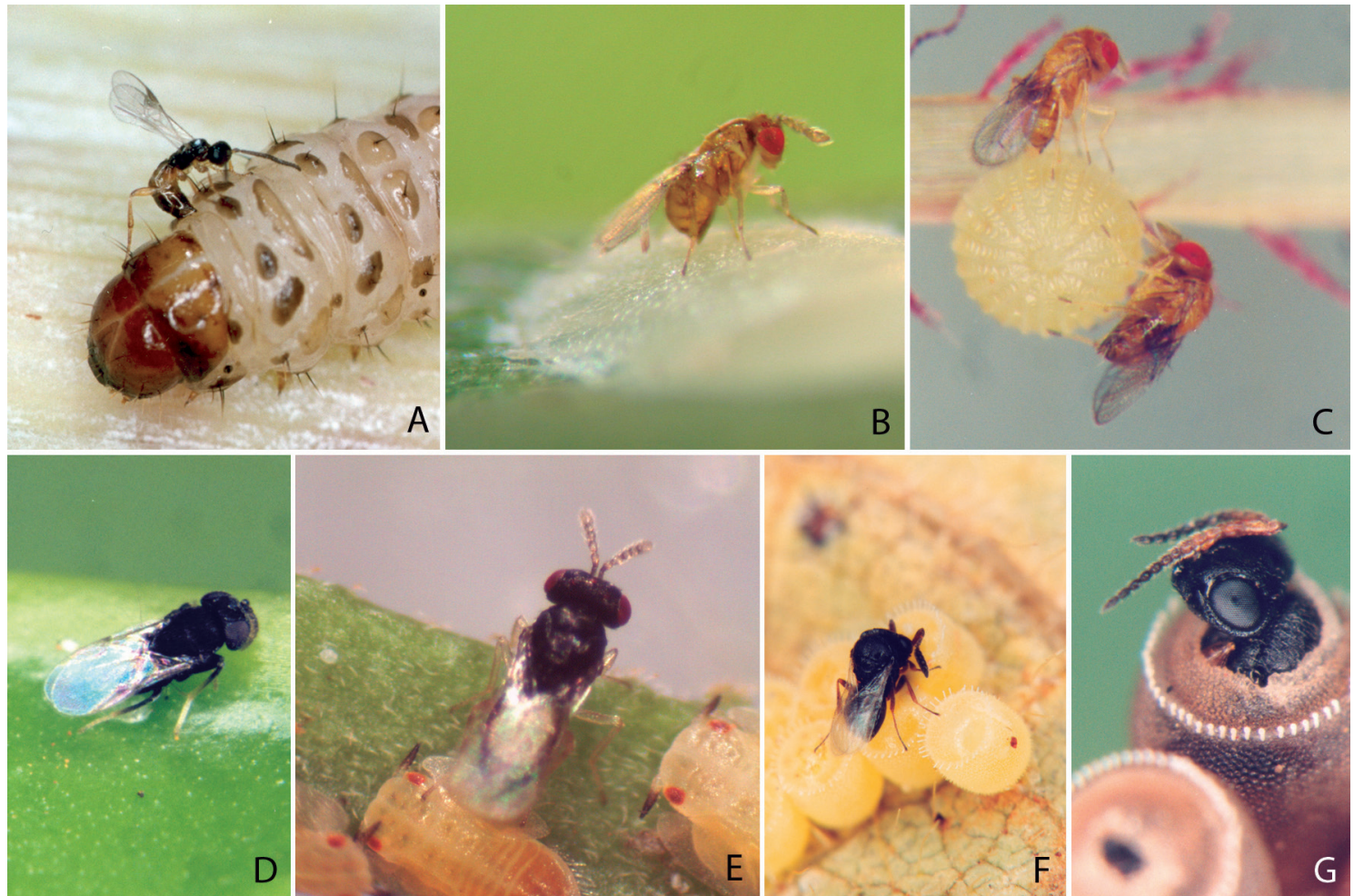

Figure 3 - The most frequently used natural enemies of crop pests in Brazil (A, B, C, D) and other potential natural enemies (E, F, G). A - Cotesia flavipes vs Diatraea saccharalis; B - Trichogramma galloi vs D. saccharalis; C - T. pretiosum vs Helicoverpa zea; D - Ageniaspis citricola vs Phyllocnistis citrella; E - Tamarixia radiata vs Diaphorina citri; F - Trissolcus basalis vs pentatomid eggs; G - Telenomus podisi vs pentatomid eggs.

commercially for the control of Ephestia elutella (Hübner) (Lepidoptera: Pyralidae) in stored tobacco - Nicotiana tabacum (Parra, J.R.P., personal information). Large farmlands of soybeans (or cotton, corn, beans - Phaseolus vulgaris, millet - Pennisetum spp. etc) require control of Chrysodeixis includens (Walker) (Lepidoptera: Noctuidae), Anticarsia gemmatalis (Hübner) (Lepidoptera: Noctuidae) or Helicoverpa armigera (Hübner) (Lepidoptera: Noctuidae). For example, in 2014, the total area treated with releases of T. pretiosum could reach 250,000 ha; B. hebetor parasitoids are released inside 1,500 tobacco warehouses by small growers to control E. elutella (Parra J.R.P., personal information). Figure 2 gives an overall view of the sugarcane area treated with BC in Brazil (Parra et al., 2010a). Small areas of tomatoes are treated with T. pretiosum for control of Tuta absoluta Meyrick (Lepidoptera: Gelechiidae) and/or Neoleucinodes elegantalis (Guenée) (Lepidoptera: Crambidae) and Helicoverpa zea (Boddie) (Lepidoptera: Noctuidae) (Parra and Zucchi, 2004).

Other BC programs have been conducted, but their results still need to be determined, as for example, a program to control the Huanglongbing (HLB) psyllid vector in Citrus with releases of Tamarixia radiata (Waterston) (Hymenoptera: Eulophidae) (Parra et al., 2010b; Diniz, 2013), and a program targeting the bronze bug $T$. peregrinus using the egg parasitoid $C$. noackae (Rodrigues et al., 2013).

Problems and challenges in implementing BC programs in large areas in Brazil

Although the use of $\mathrm{BC}$ has grown in Brazil, there is a need to develop our own technology to apply BC to huge crop areas in the country. The main challenges are:

1 - Grower's Culture: the typical Brazilian grower is used to the culture of applying agrochemicals and is uninformed about $\mathrm{BC}$ and how to use it;

2 - Technology Transfer: to extend the use of BC, it is necessary to have effective extension services, which are, unfortunately, still undeveloped in Brazil. Extension field days are needed, to demonstrate what $\mathrm{BC}$ is and how a given $\mathrm{BC}$ agent parasitizes or preys on pests;

3 - Pest Monitoring: well-defined pest monitoring methods exist for small areas, but for huge areas of Central Brazil, as are found in the states of Goiás, Mato Grosso, Mato Grosso do Sul, Bahia, Maranhão and others, methods employed for monitoring pest populations must be compatible with the size of the area. Techniques 
using pheromones and remote sensing will need to be developed;

4 - Availability of biological input: considering the extensive land area dedicated to agriculture in Brazil (around 76 million ha of cultivated area in 2014), no company is large enough to meet the entire market demand;

5 - Quality of biological input: As in any activity, there are good and bad companies involved in producing natural enemies and/or pathogens. Companies that produce poor-quality $\mathrm{BC}$ agents might eventually discredit the value of $\mathrm{BC}$ for growers. Therefore, quality control of laboratory-produced insects is essential, as is the establishment of standards for monitoring insect quality (Lenteren, 2003);

6 - Logistics of storage and transport: considering the size of the country, if companies do not take care in storing and transporting Biological Control agents, especially insects, the product may arrive at the final destination under inadequate conditions for use, parasitization, or predation of a given pest. In many cases, by the time the product is received by the user, the natural enemies are already dead or unable to emerge. If natural enemies are not properly protected at the time of the release, high temperatures often encountered in the field (on plant or soil surface) can affect their emergence;

7 - Adequate legislation for natural enemies: legislation on this topic is still incipient in Brazil and was adapted from regulations for chemical pesticides. Despite the presence of the ABCBio (Brazilian Association of Biological Control Companies) and its involvement in regulation of this sector, much still needs to be done. Recent international discussions on "Access and Benefit Sharing" must be taken into consideration (Cock et al., 2010; Lenteren et al., 2011; Coutinot et al., 2013);

8 - Chemical pesticide selectivity: $B C$ must not be considered in isolation, but rather within the context of IPM. Accordingly, if pesticides are needed, they must be selective, i.e. they must kill the pests but not the natural enemies;

9 - Release Technology: In contrast to many European countries where BC is used, Brazil has an enormously diverse fauna, including many ant species. These ants can prey on natural enemies when they are exposed and susceptible. In the case of Trichogramma, its release is effected by exposing pieces of stiff cardboard with parasitized eggs in the crop, and predation by ants can reach $100 \%$ within $2 \mathrm{~h}$ after the release. Therefore, releases must be conducted in such a manner as to protect the natural enemies from predation, such as enclosure in starch capsules for Trichogramma. In large crop areas in Brazil, releases cannot be done by farmhands on foot, which is impractical and time-consuming. The methods of releasing natural enemies must be rapid and effective. To control $H$. armigera, BC companies are employing men riding motorcycles to spread natural enemies in the field. Other means have been studied to enhance the release of natural enemies in large crops, such as the use of drones or airplanes;

10 - Dynamic Agriculture: Brazilian agriculture is highly dynamic, with continual changes in farmland, climatic and edaphic conditions, planting systems (for example, no-tillage and off-season crop in recent years), irrigation, crop succession and rotation, new varieties, and introductions of new pests such as $H$. armigera, recently reported in the country. All these factors lead to changes in the beneficial and pest entomofauna. The diversity of crop pests as well as their habits change constantly, an effect that is reinforced by the massive use of chemical products;

11 - Transgenic Plants: An extensive land area $(40$ million ha) is now planted with transgenic plants (Bt technology), which can control lepidopteran and coleopteran pests, but not sucking insects (Wolfenbarger et al., 2008; Hagenbucher et al., 2014). This partial control leads to changes in the beneficial fauna as well as in the pests, and, therefore, requires appropriate adjustments in the use of BC.

\section{Final Remarks}

Brazil, a leader in the development of tropical agriculture, will have to create a $\mathrm{BC}$ model adapted to the local conditions, extensive farmlands, and dynamic features of its agricultural system. This dynamism leads to continual changes in beneficial and pest populations because of the different farming systems used, such as notillage, continuity of crops, crop succession and rotation, irrigation, new varieties, large-scale use of transgenic plants, emergence of new pests, etc. Additionally, Brazil is progressively becoming an exporting country and, therefore, must adapt to international market requirements for chemical residues, which create difficulties in achieving a sustainable agriculture, an urgent issue in modern times.

$\mathrm{BC}$ must be implemented as one contributive component of IPM, since it is difficult to control pest populations using $\mathrm{BC}$ alone. Irrespective of whether natural enemies are released in an inoculative way (Classical Biological Control) or inundative (Applied or Augmentative Biological Control), BC must conform to the basic principles of IPM. In the case of crops that have numerous pests, when agrochemicals are necessary, selective products, as well as rotation of active ingredients, should be employed in order to prevent pests from developing resistance (Conservative Biological Control).

In any event, the culture of applying agrochemicals prevalent among growers hampers the progress of 
BC in Brazil, despite the excellent results described in this review. The pressure exerted by multinational pesticide companies leads to retrocessions, as happened with soybeans, when the virus Baculovirus anticarsia was used to control the velvetbean caterpillar on 2 million ha in the 1980s and 1990s. The use of this virus has since drastically declined, and today the total area treated area is less than 200,000 ha.

The recent introduction of $H$. armigera into the country (Czepak et al., 2013) may be a landmark in the history of $\mathrm{BC}$, as there is no chemical available for its control. In this case, growers have begun to implement IPM to control $H$. armigera by adopting crop-free periods, establishing appropriate crop refuges for transgenic plants, and using appropriate kinds of selective chemicals, as well as biological products (Degrande and Omoto, 2013), viruses, and T. pretiosum. Nevertheless, the amount of $\mathrm{BC}$ agents available for use on $H$. armigera-infested areas is insufficient, because this pest attacks more than 180 hosts. Recently, companies have started producing highquality natural enemies for combating this pest.

Approximately 230 species of natural enemies are available for purchase worldwide (Lenteren, 2012). In Brazil, the number of available BC agents is limited to ten species of insects and mites only (Parra, 2011). Because few companies are presently marketing BC agents in Brazil, adequate quantities of natural enemies are available for sugarcane only, because mills that produce sugar and ethanol have their own natural enemy production laboratories. However, nowadays most BC agents are produced by private companies specialized in controlling sugarcane pests (Parra, 2010b).

Of the 230 species of natural enemies available worldwide, 219 (95\%) are arthropods. These include 120 hymenopterans (52\%), 30 species of mites (13\%), 28 coleopterans $(12 \%), 19$ heteropterans $(8 \%)$ and 22 species of other orders (10\%) (Lenteren, 2012). The degree of specialization of parasitoids, which generally have a narrow range of hosts, ensures their superiority as $\mathrm{BC}$ agents.

The current extensive use of chemicals in citrus, soybean and cotton crops in Brazil results in unbalanced systems, where BC cannot be established. In order to enhance BC in Brazil, production systems must be planned in the context of the enormous climatic and edaphic diversity of our country, so as to take advantage of our biodiversity in $\mathrm{BC}$ programs in tropical regions. It is important not to restrict programs to mimic the technology used in countries with different characteristics and conditions because such methods have proved, on the whole, to be inefficient in Brazil.

\section{Acknowledgements}

I am grateful to Prof. Carlos F. Wilcken (UNESP - Botucatu), Luiz Alexandre Nogueira de Sá (Embrapa Environment), Gustavo Ranzani Herrmann (Koppert Brasil),Prof. Alexandre de Sene Pinto (Moura Lacerda
University - Centro Universitário Moura Lacerda) for providing useful information presented in this review, and Maria Fernanda G. V. Peñaflor for formatting the manuscript.

\section{References}

Alves, S.B. 1986. Microbial Control of Insects = Controle Microbiano de Insetos. Manole, São Paulo, SP, Brazil (in Portuguese).

Alves, S.B. 1998. Microbial Control of Insects = Controle Microbiano de Insetos. FEALQ, Piracicaba, SP, Brazil (in Portuguese).

Alves, S.B.; Lopes, R.B. 2008. Microbial Pest Control in Latin America $=$ Controle Microbiano de Pragas na América Latina . FEALQ, Piracicaba, SP, Brazil (in Portuguese).

Bennet, F.D. 1992. Potential for biological control of selected pests of importance in Latin America. p. 119-125. In: Abstract of $3^{\text {rd }}$ SICONBIOL, EMBRAPA, Águas de Lindóia, SP, Brazil.

Bento, J.M.S.; Moraes, G.J.; Matos, A.P.; Warumby, J.F.; Bellotti, A.C. 2002. Biological control of cassava mealybug in Northeast Brasil = Controle biológico da cochonilha da mandioca no Nordeste do Brasil. p. 395-408. In: Parra, J.R.P.; Botelho, P.S.M.; Corrêa-Ferreira, B.S.; Bento, J.M.S., eds. Biological control in Brazil: parasitoids and predators $=$ Controle biológico no Brasil: parasitóides e predadores. Manole, São Paulo, SP, Brazil (in Portuguese).

Bosch, R. van den; Messenger, P.S.; Gutiérrez, A.P. 1982. An Introduction to Biological Control. Plenum Press, New York, NY, USA.

Botelho, P.S.M.; Macedo, N. 2002. Cotesia flavipes for controlling Diatraea saccharalis $=$ Cotesia flavipes para o controle de Diatraea saccharalis. p. 409-425. In: Parra, J.R.P.; Botelho, P.S.M.; CorrêaFerreira, B.S.; Bento, J.M.S., eds. Biological control in Brazil: parasitoids and predators $=$ Controle Biológico no Brasil: Parasitóides e Predadores. Manole, São Paulo, SP, Brazil (in Portuguese).

Bueno, V.H.P. 2000. Biological Pest Control: Mass Production and Quality Control = Controle Biológico de Pragas: Produção Massal e Controle de Qualidade. Editora da UFLA, Lavras, MG, Brazil (in Portuguese).

Bueno, V.H.P. 2009. Biological Pest Control: Mass Production and Quality Control = Controle Biológico de Pragas: Produção Massal e Controle de Qualidade. 2ed. Editora da UFLA, Lavras, MG, Brazil (in Portuguese).

Carson, R. 1962. Silent Spring. Houghton Mifflin, Boston, MA, USA.

Cock, M.J.W.; Lenteren, J.C. van; Brodeur, J.; Barratt, B.I.P.; Bigler, F.; Bolckmans, K.; Cônsoli, F.L.; Haas, F.; Mason, P.G.; Parra, J.R.P. 2010. Do new access and benefit sharing procedures under the convention on biological diversity threaten the future of biological control? BioControl 55: 199-218.

Cohen, A.C. 2004. Insect Diets: Science and Technology. CRS Press, Cleveland, OH, USA.

Cônsoli, F.L.; Parra, J.R.P. 1999. Development of an artificial host egg for in vitro egg laying of Trichogramma galloi and T. pretiosum using plastic membranes. Entomologia Experimentalis et Applicata 91: 327-336.

Cônsoli, F.L.; Parra, J.R.P.; Zucchi, R.A. 2010. Egg Parasitoids in Agroecosystems with Emphasis on Trichogramma. Springer, New York, NY, USA. 
Corrêa-Ferreira, B.S. 2002. Trissolcus basalis for controlling soybean stinkbugs $=$ Trissolcus basalis para controle de percevejos da soja. p. 449-476. In: Parra, J.R.P.; Botelho, P.S.M.; Corrêa-Ferreira, B.S.; Bento, J.M.S., eds. Biological control in Brazil: parasitoids and predators $=$ Controle biológico no Brasil: parasitoides e predadores. Manole, São Paulo, SP, Brazil (in Portuguese).

Coutinot, D.; Briano, J.; Parra, J.R.P.; Sá, L.A.N.; Cônsoli, F.L. 2013. Exchange of natural enemies for biological control: is it a Rocky Road? - The road in the Euro- Mediterranean region and the South American common market. Neotropical Entomology 42: 1-14.

Czepak, C.; Albernaz, K.C.; Vivan, L.M.; Guimarães, H.O.; Carvalhais, T. 2013. First reported occurrence of Helicoverpa armigera (Hübner) (Lepidoptera: Noctuidae) in Brazil. Pesquisa Agropecuária Tropical 43: 110-113 (in Portuguese, with abstract in English).

Degrande, P.E.; Omoto, C. 2013. Stopping losses = Estancar prejuízos. Cultivar 15: 30-34 (in Portuguese).

Dias, N.S.; Parra, J.R.P.; Cônsoli F.L. 2010. Egg laying and development of Neotropical trichogrammatid species in artificial eggs. Entomologia Experimentalis et Applicata 137: 126-131.

Diniz, A.J.F. 2013. Optimization of rearing methods for Diaphorina citri Kuwayama, 1908 (Hemiptera: Liviidae) and Tamarixia radiata (Waterston, 1922) (Hymenoptera: Eulophidae), for largescale production and field establishment of the parasitoid. Thesis, ESALQ/USP, Piracicaba, SP, Brazil (in Portuguese, with abstract in English).

Gallo, D.; Nakano, O.; Silveira Neto, S.; Carvalho, R.P.L.; Baptista, G.C.; Berti-Filho, E.; Parra, J.R.P.; Zucchi, R.A.; Alves, S.B.; Vendramim, J.D.; Marchini, L.C.; Lopes, J.R.S.; Omoto, C. 2002. Agricultural Entomology $=$ Entomologia Agrícola. FEALQ, Piracicaba, SP, Brazil (in Portuguese).

Hagenbucher, S.; Wäckers, F.L.; Wettstein, F.E.; Olson, D.M.; Ruberson, J.R.; Romeis, J. 2014. Pest trade-offs in technology: reduced damage by caterpillars in Bt cotton benefits aphids. Proceedings of the Royal Society B: Biological Sciences 280, Doi: 10.1098/rspb.2013.0042.

Haji, F.N.P.; Prezotti, L.; Carneiro, J.S.; Alencar, J.A. 2002. Trichogramma pretiosum for controlling pests of industrial tomato $=$ Trichogramma pretiosum para o controle de pragas no tomateiro industrial. p. 477-494. In: Parra, J.R.P.; Botelho, P.S.M.; Corrêa-Ferreira, B.S.; Bento, J.M.S., eds. Biological control in Brazil: parasitoids and predators $=$ Controle biológico no Brasil: parasitóides e predadores. Manole, São Paulo, SP, Brazil (in Portuguese).

Hensley, S.D.; Hammond, A.M. 1968. Laboratory techniques for rearing the sugarcane borer on an artificial diet. Journal of Economic Entomology 61: 1742-1743.

Kogan, M. 1998. Integrated pest management: historical perspectives and contemporary development. Annual Review of Entomology 43: 243-270.

Leppla, N.C.; Williams, D.W. 1992. Mass rearing beneficial insects and the renaissance of biological control. Pesquisa Agropecuária Brasileira 27: 231-238.

Li-Ying, L.-Y.; Liu, W.-H.; Chen, C.-S.; Han, S.-C.; Shin, J.-C.; Du, H.-S.; Feng, S.Y. 1988. In vitro rearing of Trichogramma spp. and Anastatus sp. in artificial "eggs" and the methods of mass production. Colloques de l'INRA 43: 339-352.
Magro, S.R.; Parra, J.R.P. 2004. Comparison of artificial diets for rearing Bracon hebetor Say (Hymenoptera: Braconidae). Biological Control 29: 341-347.

Moraes, G.W.G.; Brun, P.G.; Soares, L.A. 1983. Insects $\times$ insects: a new alternative for pest control $=$ Insetos $\times$ insetos: nova alternativa para o controle de pragas. Ciência Hoje 1: 70-77 (in Portuguese).

Parra, J.R.P. 2001. Insect rearing techniques for Biological Control Programs = Técnicas de Criação de Insetos para Programas de Controle Biológico. FEALQ, Piracicaba, SP, Brazil (in Portuguese).

Parra, J.R.P. 2008. Mass rearing of natural enemies. p. 2301-2305. In: Capinera, J.L., ed. Encyclopedia of Entomology. 2ed. Springer, Heidelberg, Germany.

Parra, J.R.P. 2010a. Mass rearing of egg parasitoids for biological control programs. p. 267-292. In: Cônsoli, F.L.; Parra, J.R.P.; Zucchi, R.A., eds. Egg parasitoids in agroecosystems with emphasis on Trichogramma. Springer, Heidelberg, Germany.

Parra, J.R.P. 2010b. Egg parasitoids commercialization in the new world. p. 373-388, In: Cônsoli, F.L.; Parra, J.R.P.; Zucchi, R.A, eds. Egg parasitoids in agroecosystems with emphasis on Trichogramma. Springer, Heidelberg, Germany.

Parra, J.R.P. 2011. Biological Control of Pests in Brazil: history, current status and perspectives $=$ Controle biológico de pragas no Brasil: histórico, situação atual e perspectivas. Ciência e Ambiente 43: 7-18 (in Portuguese).

Parra, J.R.P.; Bento, J.M.S.; Chagas, M.C.M.; Yamamoto, P.T. 2004. Biological Control of Citrus leafminer $=\mathrm{O}$ controle biológico da larva-minadora-dos-citros. Visão Agrícola 2: 64-67 (in Portuguese).

Parra, J.R.P.; Botelho, P.S.M.; Corrêa-Ferreira, B.; Bento, J.M.S. 2002. Biological control in Brazil: parasitoids and predators $=$ Controle Biológico no Brasil no Brasil: Parasitoides e Predadores. Manole, São Paulo, SP, Brazil (in Portuguese).

Parra, J.R.P.; Zucchi, R.A. 1997. Trichogramma and the Applied Biological Control = Trichogramma e o Controle Biológico Aplicado. FEALQ, Piracicaba, SP, Brazil (in Portuguese).

Parra, J.R.P.; Zucchi, R.A. 2004. Trichogramma in Brazil: feasibility of use after twenty years of research. Neotropical Entomology 33: 271-284.

Parra, J.R.P.; Botelho, P.S.M.; Pinto, A.S. 2010a. Biological control of pests as a key component for sustainable sugarcane production. p. 441-450. In: Cortez, L.A.B., ed. Sugarcane bioethanol: R\&D for productivity and sustainability. Blücher, São Paulo, SP, Brazil.

Parra, J.R.P.; Lopes, J.R.S.; Gomez-Torres, M.L.; Nava, D.E.; Paiva, P.E.B. 2010b. Biology and ecology of the vector Diaphorina citri and transmission of bacteria associated with huanglongbing. Citrus Research and Technology 31: 37-51 (in Portuguese, with abstract in English).

Parra, J.R.P.; Costa, V.A.; Pinto, A.S. 2011. Insect parasitoids = Insetos parasitoides. Ciência e Ambiente 43: 19-36 (in Portuguese).

Pinto, A.S.; Nava, D.E.; Rossi, M.M.; Malerbo-Souza, D.T. 2006. Biological Control of Pests in practice $=$ Controle Biológico de Pragas na Prática. Prol Editora, Barueri, SP, Brazil (in Portuguese). Rodrigues, A.P.; Barbosa, L.R.; Beltramin, F.S.; Wilcken, C.F.; Zaché, B. 2013. Innovations for Cleruchoides noackae (Hymenoptera: Mymaridae) rearing = Inovações para criação de Cleruchoides noackae (Hymenoptera: Mymaridae).In: Abstract of $13^{\text {th }}$ SICONBIOL, Bonito, MS, Brazil (in Portuguese). 
Salvadori, J.R.; Salles, L.A.B. 2002. Biological Control of wheat aphids = Controle biológico dos pulgões do trigo. p. 427-447. In: Parra, J.R.P.; Botelho, P.S.M.; Corrêa-Ferreira, B.S.; Bento, J.M.S., eds. Biological control in Brazil: parasitoids and predators $=$ Controle biológico no Brasil: parasitóides e predadores. Manole, São Paulo, SP, Brazil (in Portuguese).

Schneider, J.C. 2009. Principles and Procedures for Rearing High Quality Insects. Mississippi State University, Mississippe State, MS, USA.

Silva, A.G.D.A.; Gonçalves, C.R.; Galvão, D.M.; Gonçalves, A.J.L.; Gomes, J.; Silva, M.N.; Simoni, L., eds. 1968. Fourth Catalogue of Insects Living on Plants in Brazil, their Parasites and Predators. Part II $1^{\text {st }}$ issue: Insects, Hosts and Natural Enemies = Quarto Catálogo dos Insetos que Vivem nas Plantas do Brasil, seus Parasitos e Predadores. Parte II $1^{\circ}$ Tomo: Insetos, Hospedeiros e Inimigos Naturais. Ministério da Agricultura, Rio de Janeiro, RJ, Brazil (in Portuguese).

Singh, P. 1977. Artificial Diets for Insects, Mites and Spiders. Plenum Press, Chicago, IL, USA.
Singh, P.; Moore, R.F. 1985. Handbook of Insect Rearing. Elsevier, Amsterdam, The Netherlands.

Smith, C.N. 1966. Insect Colonization and Mass Production. Academic Press, San Diego, CA, USA.

Lenteren, J.C. van. 2003. Quality control and Production of Biological Control Agents: Theory and Testing Procedures. CABI, Wallingford, UK.

Lenteren, J.C. van. 2012. The state of commercial augmentative biological control: plenty of natural enemies, but a frustrating lack of uptake. BioControl 57: 1-20.

Lenteren, J.C. van; Bueno, V.H.P. 2003. Augmentative biological control of arthropods in Latin America. BioControl 48: 123-139.

Lenteren, J.C. van; Cock, M.J.W.; Brodeur, J.; Barratt, B.I.P.; Bigler, F.; Bolckmans, K.; Haas, F.; Mason, P.G.; Parra, J.R.P. 2011. Will the Convention on Biological Diversity put an end to biological control? Revista Brasileira de Entomologia 55: 1-5.

Wolfenbarger, L.L.; Naranjo, S.E.; Lundgren, J.G.; Bitzer, R.J.; Watrud, L.S. 2008. Bt crop effects on functional guilds of nontarget arthropods: a meta-analysis. Plos One 3: e2118. 